\title{
MODEL PEMBELAJARAN DISKUSI KELOMPOK BERNOMOR DALAM PEMBELAJARAN MEMBACA PEMAHAMAN ARTIKEL
}

\author{
Dingding Haerudin \\ Fakultas Pendidikan Bahasa dan Seni \\ Universitas Pendidikan Indonesia Bandung \\ e-mail: dingding_haerudin@yahoo.com
}

\begin{abstract}
This study aims to describe the reading ability and the effectiveness of the Numbered Group Discussion (NGD) learning model in an attempt to improve the article reading ability. It was an experimental study. The data were collected through tests, observations, questionnaires, and interviews. The participants were students of Jurusan Pen $\neg$ di $\neg$ dikan Bahasa Daerah FPBS UPI. The findings show that the NGD learning model was capable of improving the learning achievement. The students of the experimental group learning through the NGD model had an improvement of 3.70 and those of the control group had an improvement of 1.21. In terns of the mastery level, the experimental group improved from the poor category to the moderate category, while the control group was in the poor category. In the literal, inferential, and evaluation aspects, the experimental group showed an improvement from the pretest to the posttest. In relation to the learning process quality, the NGD model can be an effective method for both the students and lecturers.
\end{abstract}

Keywords: learning model, numbered group discussion, reading comprehension

\section{PENDAHULUAN}

Beragamnya temuan hasil penelitian yang menyatakan rendahnya minat maupun kemampuan membaca pada kalangan peserta didik menimbulkan kekhawatiran bagi berbagai pihak, khususnya para pendidik. Padahal, salah satu aspek yang tidak dapat dipisahkan dari proses belajar adalah kegiatan membaca. Daya serap seseorang saat membaca sangat menentukan hasil akhir dan proses belajar.

Bagi seseorang memiliki kemampuan membaca sangat penting. Rusyana (1984: 190) menyatakan bahwa memiliki kemampuan membaca membawa kita dapat bertahan di muka bumi dan mampu memelihara dan mengembangkan kehidupan, baik sebagai perseorangan maupun sebagai bangsa. Bangsa yang cerdas adalah bangsa yang mampu membaca. Agar bangsa memiliki kemampuan membaca, kebiasaan membaca perlu mendapat perhatian dan pembinaan seksama, baik pada sebuah lembaga formal maupun nonformal

Aktivitas membaca yang dilakukan dalam pembelajaran bahasa di tingkat perguruan tinggi di antaranya membaca pemahaman. Membaca pemahaman (reading comprehension) bertujuan untuk memahami isi bacaan dan mencari informasi dalam sebuah bacaan (Iskandarwassid, 2008). Dengan membaca pemahaman seorang pembaca dapat menemukan informasi tentang ide, fakta, teori-teori, dan lain-lain yang berfungsi sebagai sumber ilmu pengetahuan dan pengalaman membaca (Akhadiat, 1988).

Berkaitandengankemampuanmembaca pemahaman, Smith (1973: 231-234) menyatakan bahwa aktivitas pemahaman membaca itu meliputi aspek literal, 
inferensial, dan evaluasi. Pemahaman aspek literal merupakan kemampuan yang dimiliki pembaca dalam mengenali dan mengingat kembali rincian-rincian, ide-ide utama, dan urutan yang dinyatakan secara eksplisit dalam teks. Kemampuan membaca pemahaman aspek literal yang dianalisis dalam penelitian ini meliputi kemampuan memahami kata, kalimat, paragraf, dan rincian isi bacaan (Keraf, 2001). Pemahaman aspek inferensial merupakan kemampuan yang dimiliki pembaca dalam menemukan gagasan utama, hubungan sebabakibat, dan persamaan atau perbedaan yang dinyatakan secara tidak langsung dalam teks. Kemampuan pemahaman aspek inferensial yang dianalisis dalam penelitian ini meliputi kemampuan memahami gagasan utama, menemukan tema, hubungan sebab akibat, dan kemampuan menyimpulkan isi bacaan (Panjalu, 2008). Pemahaman aspek evaluasi merupakan bagian dari kemampuan pembaca dalam membandingkan isi bacaan dengan pengalaman yang dimiliknya, mempertanyakan maksud penulis, dan mereaksi secara kritis gaya penulis dalam me-ngungkapkan gagasan-gagasannya.

Salah satu sumber informasi yang digunakan sebagai rujukan di tingkat perguruan tinggi adalah artikel. Seperti halnya buku-buku dan berbagai jenis bacaan lainnya, artikel belum menjadi kebutuhan primer bagi kebanyakan masyarakat terdidik, khususnya mahasiswa. Sebagai masyarakat intelektual, mahasiswa memiliki kepentingan untuk membaca artikel di samping buku dan sumber bacaan lainnya, karena di dalam artikel tidak sedikit memberikan informasi yang bermanfaat dalam meningkatkan ilmu pengetahuan. Artikel yang dimaksud adalah artikel ilmiah yang isinya berhubungan materi perkuliahan.

Slavin (1994) menyatakan bahwa tujuan pembelajaran kooperatif adalah menciptakan situasi belajar di mana keberhasilan individu ditentukan atau dipengaruhi oleh keberhasilan kelompoknya. Berbeda dengan pembelajaran kelompok konvensional yang menerapkan sistem kompetisi, di mana keberhasilan individu diorientasikan pada kegagalan orang lain (Slavin, 1994).

Model pembelajaran DKB termasuk salah satu jenis model pembelajaran kooperatif yang dikembangkan pertama kali oleh Kagan (1994), yaitu Numbered Head Together (NHT). Pola penomoran dalam model ini dirancang untuk mempengaruhi kualitas interaksi pembelajaran sehingga mampu meningkatkan hasil belajar (Anshori, 2007).

Sebagai salah satu tipe pembelajaran kooperatif, model pembelajaran tersebut pada dasarnya banyak memberi berbagai keuntungan dalam meningkatkan kemampuan belajar, di antaranya dalam pembelajaran membaca. Dalam pelajaran bahasa Indonesia, keterampilan membaca merupakan bagian dan empat aspek keterampilan berbahasa lainnya, di samping menyimak, berbicara, dan menulis (Nurgiyantoro, 2001).

Joyce (2000: 302) dan Anita Lie (2007: 65) mengemukakan beberapa asumsi yang mendasari pembelajaran kooperatif (cooperative learning) di antaranya, (1) meningkatkan motivasi belajar yang jauh lebih besar dari pada dalam bentuk lingkungan kompetitif individual, karena perasaan-perasaan saling berhubungan (feelings of connectedness) mampu menghasilkan energi yang positif; (2) menghilangkan perasaan asing dan perasaan menyendiri serta sebuah pandangan positif mengenai orang lain; (3) meningkatkan kemampuan peserta didik bekerja sama dan kecakapan berhubungan sosial.

Permasalahan yang dikaji dalam penelitian ini adalah keefektifan model pembelajaran DKB dan kemampuan ma- 
hasiswa dalam membaca pemahaman artikel. Apakah model pembelajaran DKB dapat dilaksanakan dan efektif dalam meningkatkan hasil pembelajaran membaca pemahaman artikel? Hal tersebut perlu diteliti. Upaya yang dilakukan dalam penelitian ini adalah menguji keefektifan model pembelajaran Diskusi Kelompok Bernomor (DKB) dalam pembelajaran membaca artikel.

\section{METODE PENELITIAN}

Metode yang digunakan dalam penelitian ini ialah metode eksperimen (experimental research). Penelitian ini termasuk ke dalam jenis eksperimen murni atau eksperimen yang sebenarnya (true experimental). Desain penelitian yang digunakan dalam penelitian ini adalah rancangan kelompok kontrol tes awaltes akhir secara acak (randomized pretestposttest control group design). Karakter desain penelitian ini mengacu pada kegiatan pengukuran terhadap dua kelompok subjek yaitu kelompok perlakuan dan kelompok pembanding (kontrol).

Dalam penelitian eksperimen ini terdapat dua macam variabel, yaitu variabel bebas dan variabel terikat. Variabel bebas pada kelompok perlakuan (eksperimen) ialah model pembelajaran $\mathrm{DKB}$, sedangkan variabel bebas pada kelompok pembanding (kelompok kontrol) ialah model pembelajaran konvensioan. Variabel terikat dari kedua kelompok perlakuan tersebut, adalah kemampuan membaca pemahaman artikel.

Teknik yang digunakan dalam penelitian ini meliputi teknik pengumpulan data dan teknik pengolahan data. Data yang dikumpulkan dalam penelitian ini diperoleh dari hasil tes, observasi, wawancara, dan angket.

Teknik tes digunakan untuk menjaring data atau informasi tentang kemampuan membaca pemahaman artikel. Pelaksanaan tes bagi kelas eksperimen dilaksanakan sebelum dan sesudah mendapat perlakuan model pembelajaran DKB dalam pembelajaran membaca pemahaman artikel. Pelaksanaan tes bagi kelas pembanding (kontrol) dilakukan sebelum dan sesudah mendapat perlakuan dengan model pembelajaran konvensional (Fraenkel, 1993).

Teknik observasi dalam penelitian ini digunakan untuk mengumpulkan data dari hasil pengamatan selama perlakuan pada kelas eksperimen dan kelas kontrol (Ari Kunto, 1955).

Data yang diperoleh dari hasil observasi digunakan untuk mendeskkripsikan kualitas proses pembelajaran membaca pemahaman artikel menggunakan model pembelajaran DKB pada kelas eksperimen dan pembelajaran konvensional pada kelas kontrol.

Teknik angket digunakan untuk memperoleh informasi berupa kesan, tanggapan, dan penilaian (subjek eksperimen)mengenai model pembelajaran DKB dalam kegiatan pembelajaran membaca pemahaman artikel. Mahasiswa sebagai responden dianggap sudah matang atau berkemampuan dalam mengemukakan tanggapan dan penilaian secara tertulis. Teknik ini digunakan karena data yang diperlukan adalah berupa tanggapan, pendapat, atau penilaian.

Teknik wawancara digunakan untuk mengumpulkan data atau informasi berupa pendapat, tanggapan, kesan, dan penilaian dosen pelaksana perlakuan mengenai model pembelajaran DKB dalam pembelajaran membaca pemahaman artikel. Informasi yang diperoleh dari hasil wawancara dijadikan bahan pertimbangan rekomendasi bagi pengukuhan atau penyempumaan model tersebut. Wawancara dengan narasumber dipandu dengan sebuah pedoman wawancara berupa daftar pertanyaan.

Data yang terkumpul kemudian diolah menggunakan rumus-rumus statistik yang diolah dengan program Excel. Program Excel digunakan untuk 
mencari validitas, reliabilitas instrumen, dan mengolah uji sifat data dan uji hipotesis penelitian.

\section{HASIL DAN PEMBAHASAN Keefektifan Model Pembelajaran DKB}

Berdasarkan hasil analisis penelitian, model pembelajaran DKB yang diterapkan selama empat kali perlakuan efektif meningkatkan kemampuan membaca pemahaman mahasiswa kelas eksperimen. Hal ini dapat dilihat dari perbandingan rata-rata hasil tes awal dan tes akhir yang diperoleh antara mahasiswa kelas eksperimen dan kelas kontrol. Mahasiswa kelas eksperimen yang mendapat perlakuan model DKB meningkat sebesar 3,70 yaitu dari skor rata-rata 10,55 menjadi 14,24, sedangkan mahasiswa kelas kontrol meningkat sebesar 1,21 yaitu dari skor rata-rata 10,82 menjadi 12,03 . Peningkatan kemampuan membaca pemahaman mahasiswa kelas eksperimen lebih tinggi sebesar 2,92 dari mahasiswa kelas kontrol.

Berdasarkan hasil uji hipotesis yang dilakukan dengan uji perbedaan dua rata-rata menggunakan uji $\mathrm{Z}$ pada hasil tes akhir kelas eksperimen dan tes akhir kelas kontrol, terbukti bahwa terdapat perbedaan yang signifikan pada taraf $\alpha=0,05$. Diketahui bahwa angka Zhitung $(6,18)$ lebih besar dari Ztabel $(2,04)$ pada $(\alpha=0,05)$. Artinya, ada perbedaan yang signifikan pada taraf $95 \%$ antara kemampuan akhir kelas eksperimen dan kemampuan akhir kelas kontrol dalam membaca pemahaman artikel.

Dari hasil perhitungan di atas dapat diketahui bahwa terdapat perbedaan kemampuan membaca pemahaman artikel antara mahasiswa kelas eksperimen yang menggunakan model pembelajaran DKB dengan mahasiswa kelas kontrol yang menggunakan pembelajaran konvensional. Jadi, hipotesis nol (Ho), yaitu tidak terdapat perbedaan antara kemampuan rata-rata akhir kelas eksperimen dan kemampuan akhir kelas kontrol dalam membaca pemahaman artikel ditolak dan Hi diterima.

Dengan demikian dapat disimpulkan bahwa model pembelajaran DKB lebih efektif dalam meningkatkan kemampuan membaca pemahaman artikel pada mahasiswa kelas eksperimen Jurusan Pendidikan Bahasa Daerah FPBS UPI. Pada hasil penelitian ini ditemukan bahwa tingkat penguasaan membaca pemahaman mahasiswa kelas eksperimen sebelum perlakuan pembelajaran menggunakan model DKB berada pada kategori kurang yaitu 52,73\%, setelah memperoleh perlakuan pembelajaran menggunakan model DKB berada pada kategori cukup yaitu $71,21 \%$. Tingkat penguasaan membaca pemahaman mahasiswa kelas kontrol sebelum perlakuan pembelajaran menggunakan model konvensional berada pada kategori kurang yaitu $54,12 \%$, setelah perlakuan pembelajaran masih berada pada kategori kurang yaitu 60,15\%.

Meningkatnya kemampuan mahasiswa kelas eksperimen dalam membaca pemahaman artikel dipengaruhi perlakuan model pembelajaran DKB. Selama pembelajaran menggunakan model tersebut 1) mahasiswa terlibat dalam kegiatan belajar kelompok secara aktif, sehingga suasana kelas lebih hidup dan lebih bermakna, 2) dosen model turut membantu jalannya diskusi, seperti turut mengidentifikasi kesulitan-kesulitan yang dihadapi mahasiswa dan berusaha bersama-sama mencarikan alternatif pemecahannya, 3) dosen bertindak sebagai fasilitator dan moderator, di samping menciptakan suasana pembelajaran yang demokratis. Temuan tersebut sejalan dengan pendapat Sunal dan Hans dalam Isjoni (2009:14) yang menyatakan bahwa pembelajaran kooperatif memiliki serangkaian strategi 
atau cara yang dirancang khusus untuk memberi dorongan kepada peserta didik agar bekerja sama selama proses pembelajaran. Di samping itu, pembelajaran kooperatif dapat meningkatkan hasil belajar, meningkatkan motivasi belajar dan meningkatkan kemampuan berkolaborasi yang merupakan bagian dari perilaku sosial.

\section{Kualitas Model Pembelajaran DKB Berdasarkan Hasil Observasi}

Sesuai dengan pedoman yang digunakan, hasil observasi terbagi atas lima bagian, yaitu (1) kegiatan dosen dan mahasiswa, (2) sistem sosial kelas, (3) prinsip-prinsip reaksi, (4) sistem penunjang, dan (5) penerapan.

Kegiatan Dosen selama empat kali perlakuan di kelas eksperimen telah sesuai dengan langkah-langkah yang diharapkan dalam model ini, yaitu mencapai 89,47\%. Beberapa hal penting yang berkaitan dengan kegiatan dosen dalam melaksanakan model ini adalah: (a) dosen terlebih dahulu menyamakan persepsi tentang model pembelajaran yang akan dilaksanakan, mulai rasionalisasi, tujuan, sampai prosedur pelaksanaannya; (b) dosen telah menunjukkan sikap yang bersungguh-sungguh dalam melaksanakan pembelajaran sesuai dengan langkah-langkah pembelajaran model ini; (c) Selama diskusi berlangsung dosen tidak hanya bertindak sebagai moderator, tetapi turut membangkitkan semangat mahasiswa di samping menciptakan suasana kelas yang nyaman dan kekeluargaan; (d) dosen menciptakan suasana dan interaksi pembelajaran yang dinamis dan bervariasi, sesuai dengan karakter pembelajaran kooperatif, baik interaksi antara dosen dengan mahasiswa maupun antar mahasiswa; (e) dosen turut serta mengatur, mengomentari, mengarahkan jalannya diskusi dan memberikan penghargaan berupa pujian pada hasil pekerjaan individu maupun kelompok; (f) dosen berusaha memacu semangat mahasiswa dalam meningkatkan kualitas keterampilan berbahasa lainnya seperti berbicara dan menyimak, di samping kemampuan membaca dalam hati.

Kegiatan Mahasiswa selama empat kali perlakuan secara keseluruhan mencapai kurang lebih 90,27\%. kegiatan mahasiswa tersebut, dapat disimpulkan bahwa selama pembelajaran berlangsung mahasiswa telah melakukan kegiatan secara optimal.

Minat belajar dan rasa ingin tahu mengikuti perkuliahan membaca dengan model pembelajaran DKB mulai nampak setelah dosen menjelaskannya terlebih dahulu. Saat diskusi berlangsung, semua mahasiswa terlibat aktif dan menunjukkan sikap kritis dalam menjawab setiap pertanyaan.

Beberapa hal penting yang berkaitan dengan kegiatan mahasiswa dalam mengikuti pembelajaran menggunakan model ini adalah: (a) diskusi kelompok berjalan dengan tertib, ketekunan belajar meningkat, dan sangat serius mengerjakan tugas-tugasnya; (b) interaksi dan kerjasama antar anggota kelompok semakin baik, dan tampak ada kegiatan saling membantu di antara mereka; (c) kepercayaan diri setiap anggota kelompok dalam mempresentasikan hasil pekerjaannya semakin meningkat; (d) aktivitas dan partisipasi mereka dalam menanggapi presentasi kelompok lain semakin baik, tertib, dan lancar.

Sistem sosial kelas yang berlangsung selama pembelajaran DKB lebih berpusat pada mahasiswa. Aktivitas mahasiswa muncul dari struktur pembelajaran yang telah ditetapkan dosen pada awal pembelajaran. Dosen berperan sebagai fasilitator yang mengarahkan mahasiswa melaksanakan langkahlangkah yang harus ditempuh selama pembelajaran, baik kegiatan yang dilakukan individu maupun kegiatan ke- 
lompok.

Dosen memberi kebebasan kepada mahasiswa untuk bertanya jawab dan saling bertukar pikiran tentang isi artikel. Dosen nampak berusaha menghargai setiap mahasiswa. Di sela-sela kegiatan diskusi nampak dosen manggut-manggut atau mengacungkan jempol tanda setuju terbadap jawaban yang disampaikan kelompok penyaji atau anggota kelompok lainnya yang berkomentar. Dosen berusaha mena-nyakan kepada warga kelas ketika ada jawaban salah seorang anggota kelompok yang tidak sesuai dengan yang seharusnya. Pertanyaan dosen memacu warga kelas untuk aktif merespon dan turut menyumbangkan pemikirannya. Suasana kelas selama diskusi berlangsung tenang, aktif, reaktif, dan komunikatif.

Keikutsertaan setiap mahasiswa selama pembelajaran cukup tinggi, karena model pembelajaran ini memang menuntut aktivitas mahasiswa (pembelajar). Mahasiswa cukup aktif dalam merespon dan memberikan tanggapan terhadap materi yang dipelajari. Aktivitas mahasiswa dalam berkolaborasi (gotong-royong) juga cukup menonjol, seperti menyumbangkan atau menghimpun setiap pekerjaan (hasil berpikir) anggota menjadi kesepakatan hasil pekerjaan bersama (Ibrahim, 2002).

Prinsip-prinsip reaksi yang ditemukan dalam model pembelajaran DKB ini menunjukkan bahwa 1) Dosen berperan sebagai fasilitator yang mengarahkan mahasiswa melaksanakan langkahlangkah yang harus ditempuh dalam kegiatan diskusi diskusi kelompok. Dosen juga berperan sebagai moderator yang mengatur kelancaran proses diskusi kelas berlangsung. 2) Mahasiswa didorong untuk mengerahkan kemampuan berpikir kreatif dalam menjawab pertanyaan dan menyampaikan jawaban, baik pada kelompoknya maupun kelompok lainnya. 3) Mahasiswa diberi kesempa- tan untuk bertanggung jawab menyelesaikan tugas baik secara individu maupun kelompok. 4) Mahasiswa mendapat kesempatan dan pengalaman membantu teman yang menemukan kesulitan menjawab pertanyaan atau menyelesaikan tugas. 5) Mahasiswa cukup responsif dalam memberikan tanggapan terhadap materi yang sedang dipelajari. 6) Diskusi berlangsung secara demokratis, yaitu mahasiswa diberi kebebasan untuk menyampaikan setiap jawaban atas setiap pertanyaan kepada seluruh anggota kelompok lainnya. 7) Mahasiswa mampu berkolaborasi (gotong-royong) dalam menyumbangkan buah pikirannya yang kemudian digabungkan menjadi kesepakatan hasil pekerjaan bersama.

Penunjang utama dalam pembelajaran membaca pemahaman menggunakan model DKB ini adalah artikel. Bahan berupa artikel dapat diperoleh dari berbagai media massa atau kumpulan artikel yang telah dibukukan penulisnya. Artikel yang dibaca mahasiswa selama pembelajaran diambil dari beberapa sumber, yaitu surat kabar, internet, dan buku kumpulan artikel. Artikel itu kemudian diperbanyak sesuai jumlah mahasiswa. Artikel yang dipilih disesuaikan dengan minat dan kebutuhan mahasiswa. Informasi yang disajikan dalam artikel disesuaikan dengan latar belakang pendidikan yang sedang mereka tempuh, yaitu masalah bahasa dan pengajaran.

Dosen memberikan salinan naskah artikel kepada semua mahasiswa, kemudian mahasiswa diberi kesempatan untuk memahami isi artikel tersebut dengan cara membaca dalam hati. Selama pembelajaran berlangsung, artikel tersebut dijadikan bahan kajian dan rujukan. Dosen dan mahasiswa bersamasama mengkaji isi artikel dalam setiap pertemuan. Dosen menginformasikan sekilas gambaran umum dan manfaat yang diperoleh dari isi artikel tersebut. 
Langkah ini dilakukan dosen untuk mengundang motivasi dan rasa penasaran mahasiswa mendalaminya.

Dampak instruksional yang diharapkan dari penggunaan model ini adalah kemampuan mahasiswa dalam membaca pemahaman artikel. Di samping memperoleh pengetahuan, mahasiswa mampu berpikir kreatif dan logis karena materi yang disajikan dalam artikel tidak hanya teori dan fakta, tetapi juga jalan pikiran penulisnya.

Dampak penyerta dari hasil pembelajaran ini adalah mahasiswa dapat memperoleh pengalaman belajar mencari informasi dalam artikel. Di samping dalam buku-buku sumber yang diwajibkan, pada artikel pun banyak disajikan informasi yang dapat dimanfaatkan sebagai rujukan materi perkuliahan yang sedang ditempuh.

\section{Kualitas Model Pembelajaran DKB Berdasarkan Hasil Angket}

Responden yang mengisi angket adalah mahasiswa sampel pada kelas eksperimen yang mendapat perlakuan model DKB dalam pembelajaran membaca pemahaman artikel. Angket yang digunakan adalah angket setengah terbuka yang terdiri dari lima butir pertanyaan, yaitu yang berkaitan dengan (1) model DKB sebagai model yang baru, (2) model DKB dapat menumbuhkan motivasi belajar, (3) model DKB mempermudah penguasaan materi perkuliahan, (4) rencana mencoba model DKB di kemudian hari, dan (5) berkaitan dengan bentuk perkuliahan yang diinginkan mahasiswa.

Berdasarkan hasil angket dapat disimpulkan bahwa dari 33 responden terdapat $97 \%$ yang menyatakan bahwa model DKB merupakan pembelajaran yang baru. Responden menyatakan bahwa model pembelajaran ini menyenangkan, melatih diri untuk berani mengemukakan gagasan dan menuntut mampu menyampaikan informasi yang diperolehnya kepada orang lain.

Ditemukan 96,97\% responden yang menyatakan dirinya termotivasi untuk mengikuti perkuliahan dengan sungguh-sungguh dalam pembelajaran membaca artikel menggunakan model DKB. Berdasarkan jawaban-jawaban pertanyaan pada angket, dapat disimpulkan bahwa model pembelajaran membaca pemahaman artikel menggunakan model pembelajaran DKB dapat meningkatkan motivasi belajar. Hal ini terbukti dengan adanya berbagai tanggapan dari responden yang menyatakan bahwa model pembelajaran DKB tidak menjenuhkan dan membosankan, memacu belajar lebih serius, menciptakan suasana belajar lebih nyaman, memancing keingintahuan, mampu memperoleh informasi yang dengan tepat, bisa bertukar pikiran, dan melatih cepat tanggap.

Ditemukan 90,90\% responden yang menyatakan model pembelajaran DKB mempermudah memahami atau menguasai materi. Berdasarkan jawaban-jawaban pertanyaan pada angket, dapat disimpulkan bahwa model pembelajaran membaca pemahaman artikel menggunakan model pembelajaran DKB mempermudah penguasaan materi. Hal tersebut dibuktikan dengan alasan dan penegasan responden yang menyatakan bahwa mereka benar-benar dapat memahami isi bacaan, terjadinya tukar pendapat dan saling membagi pengetahuan di antara mereka, dan mereka dapat memusatkan konsentrasi dalam mencari jawaban dan alternatif pemecahan masalah.

Ditemukan 90,90\% responden yang menyatakan berencana untuk mencoba mensosialisasikan teknik diskusi tersebut di kemudian hari. Hanya $03,03 \%$ responden yang tidak berencana untuk mencoba mensosialisasikan menggunakan teknik diskusi tersebut 
di kemudian hari. Berdasarkan jawaban-jawaban responden terhadap pertanyaan pada angket, dapat disimpulkan bahwa model pembelajaran membaca pemahaman artikel menggunakan model pembelajarn DKB perlu untuk disosialisasikan. Model pembelajaran ini menurut pengalaman mereka cukup menarik, menyenangkan, tidak membosankan, membangkitkan minat belajar, mempermudah menguasai materi, dan melatih daya tanggap dan mental pembelajar.

Ditemukan 18,18\% responden yang menyatakan menyenangi perkuliahan bentuk ceramah, tugas individu, atau presentasi. $24,24 \%$ yang menyenangi bentuk perkuliahan diskusi kelompok, dan 57,57\% yang menyenangi bentuk perkuliahan yang bervariasi.

Berdasarkan jawaban-jawaban responden terhadap pertanyaan pada angket, dapat disimpulkan bahwa bentuk perkuliahan yang disenangi mahasiswa tidak sama. Pada umumnya mereka lebih banyak menyenangi bentuk perkuliahan yang bervariasi. Artinya kegiatan pembelajaran tidak hanya ceramah, tugas individu atau presentasi saja, tetapi sebaiknya setiap pertemuan menggunakan metode dan teknik yang bervariasi. Hal tersebut tentunya disesuaikan dengan materi yang akan dibahas pada setiap pertemuan. Dengan demikian setiap pengajar perlu memikirkan bentuk perkuliahan yang menarik bagi mahasiswa.

\section{Kualitas Model Pembelajaran DKB Berdasarkan Hasil Wawancara}

Wawancara dilakukan dengan dosen model yang melaksanakan perlakuan model pembelajara DKB dalam membaca pemahaman artikel.

Berdasarkan hasil wawancara dengan dosen model diperoleh kesimpulan bahwa 1) sebelumnya tidak pernah melaksanakan pembelajaran den- gan model ini; 2) dosen model merasa tertarik melaksanakan model pembelajaran DKB, sebab prosedur dalam model cukup terarah, teratur, dan sistematis; 3 ) model pembelajaran DKB sangat dirasakan manfaatnya dalam meningkatkan mahasiswa dalam memahami materi; 4); selama eksperimen berlangsung dosen model telah melaksanakan dengan sungguh-sungguh model pembelajaran DKB; dan 5) bermaksud akan untuk mensosialisasikan model pembelajaran DKB sebagai model alternatif di samping model-model pembelajaran yang lainnya.

Dosen model menyatakan bahwa baru pertama kali melaksanakan pembelajaran membaca pemahaman menggunakan model pembelajaran DKB. Dikatakannya bahwa proses pembelajaran dalam model tersebut memberi kesempatan kepada mahasiswa untuk meningkatkan aktivitas dan kreativitas belajarnya. Mahasiswa dapat memperoleh materi, dapat menjawab pertanyaan yang diajukan, dan dapat berkolaborasi dengan teman baik yang sekelompok maupun kelompok lainnya. Mereka juga memiliki kesempatan membantu teman dalam mendapatkan jawaban yang lebih akurat.

Narasumber juga menjelaskan bahwa dalam pembelajaran menggunakan model DKB memberi kesempatan kepada masing-masing anggota kelompok untuk bertanggung jawab dalam menyelesaikan tugas yang akan diprsentasikan dalam diskusi. Dengan adanya aktivitas diskusi pada kelompok kecil (anggota kelompok bernomor sama) mampu meningkatkan wawasan mahasiswa, mereka tidak hanya mampun mencari jawaban, tetapi mampu membantu memecahkan persoalan yang dihadapi teman sekelompoknya.

Sebagai narasumber, dosen model juga menyatakan bahwa model pembelajaran DKB tidak sekedar melibatkan 
mahasiswa belajar dalam satu kelompok, tetapi juga efektif bagi mahasiswa memperoleh apa yang dipelajarinya. Mahasiswa yang terlibat dalam diskusi minimal memperoleh materi yang menjadi tugas bagi dirinya. Mahasiswa terlatih memiliki sikap disiplin dalam belajar terutama kreativitas dalam menjelajahi isi bacaan.

Penjelasan yang dikemukakan dosen model tidak jauh berbeda dengan yang dikemukakan mahasiswa, bahwa model pembelajaran DKB menarik. Adanya ketertarikan terhadap proses pembelajaran sedikit banyaknya mempengaruhi motivasi belajar maupun gairah mengajar. Hal itu dibuktikan dengan kualitas hasil belajar, yaitu meningkatnya kemampuan mahasiswa dalam membaca pemahaman artikel.

Salah satu manfaat dari kegiatan diskusi menggunakan model pembelajaran DKB adalah meningkatkan kualitas pembelajaran. Dosen model menyatakan bahwa prosedur yang berlangsung dalam model ini mampu menggiring mahasiswa untuk disiplin dalam belajar. Mahasiswa sejak awal mengetahui target akhir setelah membaca.

Dalam model ini target kemampuan yang harus dicapai mahasiswa sudah jelas. Pertanyaan-pertanyaan itulah yang membuat mahasiswa memacu minat membaca, karena tanpa membaca ia tidak memiliki wawasan atau pengetahuan untuk mengaktualisasikan dirinya di hadapan teman-temannya.

Narasumber yang menjadi dosen model dalam empat kali perlakuan, telah berusaha dengan sungguh-sungguh melaksanakan model pembelajaran DKB dalam pembelajaran membaca pemahaman. Bahkan di samping menerapkan model pembelajaran, narasumber mengharap mahasiswa di kemudian hari juga mengaplikasikan model itu ketika menjadi seorang guru atau pendidik.
Kesungguh-sungguhan narasumber melaksanakan model pembelajaran ini sangat menunjang terhadap meningkatnya kualitas hasil belajar mahasiswa. Hal ini dibuktikan dengan meningkatnya kemampuan mahasiswa kelas eksperimen dalam membaca pemahaman artikel.

Dosen model yang juga menjadi narasumber dalam penelitian ini berkeinginan untuk mensosialisasikan model pembelajaran DKB. Alasan yang dikemukakan bahwa selama mengimplementasikan model tersebut, tampak aktivitas mahasiswa lebih meningkat. Dikatakannya bahwa model pembelajaran ini melatih mahasiswa untuk bertanggung jawab secara individual di samping tanggung jawab kelompok. Diskusi kelompok dalam model pembelajaran tersebut mampu menciptakan proses pembelajaran yang berkualitas. Seperti halnya dalam dalam penelitian ini, model pembelajaran DKB mampu meningkatkan kemampuan mahasiswa kelas eksperimen dalam membaca pemahaman artikel.

\section{SIMPULAN}

Sesuai dengan tujuan penelitian yang dikemukakan dalam Bab I, pada bagian ini dikemukakan simpulan hasil penelitian sebagai berikut.

1) Model pembelajaran Diskusi Kelompok Bernomor $(D K B)$ efektif dalam meningkatkan kemampuan hasil belajar membaca pemahaman artikel pada mahasiswa Jurusan Pendidikan Bahasa Daerah Fakultas Pendidikan Bahasa dan Seni Universitas Pendidikan Indonesia.

2) Aspek-aspek yang terdapat dalam membaca pemahaman artikel pada penelitian ini meliputi aspek literal, inferensial, dan aspek evaluasi. Meskipun peningkatan setiap aspek dalam membaca pemahaman artikel tersebut belum optimal, perbedaan 
rata-rata hasil tes awal dan tes akhir cenderung meningkat.

3) Tingkat penguasaan membaca pemahaman mahasiswa kelas eksperimen sebelum perlakuan pembelajaran menggunakan model DKB berada pada kategori kurang yaitu 52,73\%, setelah memperoleh perlakuan pembelajaran menggunakan model DKB berada pada kategori cukup yaitu $71,21 \%$. Tingkat penguasaan membaca pemahaman mahasiswa kelas kontrol sebelum perlakuan pembelajaran menggunakan model konvensional berada pada kategori kurang yaitu $54,12 \%$, setelah perlakuan pembelajaran masih berada pada kategori kurang yaitu 60,15\%.

4) Terdapat perbedaan yang signifikan antara kemampuan awal dan kemampuan akhir mahasiswa kelas eksperimen. Hasil uji hipotesis menggunakan uji $\mathrm{Z}$ menunjukkan bahwa Z hitung $(7,81)>Z$ tabel $(0,47)$ pada $(\alpha=0,05)$. Begitu juga antara kemampuan akhir kelas eksperimen dan kemampuan akhir kelas kontrol. Hasil uji hipotesis menggunakan uji $\mathrm{Z}$ menunjukkan bahwa $\mathrm{Z}$ hitung $(6,18)>Z$ tabel $(2,04)$ pada $(\alpha=0,05)$. Terdapatnya perbedaan antara hasil tes awal dan tes akhir mahasiswa kelas eksperimen menunjukkan bahwa model pembelajaran DKB efektif meningkatkan kemampuan membaca pemahaman mahasiswa kelas eksperimen. Terdapatnya perbedaan antara hasil tes akhir mahasiswa kelas eksperimen yang mendapat perlakuan model pembelajaran DKB dengan hasil tes akhir mahasiswa kelas kontrol yang mendapat perlakuan model pembelajaran konvensional, menunjukkan bahwa model DKB lebih efektif daripada model konvensional dalam meningkatkan kemampuan membaca pemahaman artikel mahasiswa JPBD FPBS UPI.
5) Dosen model telah melaksanakan seluruh rangkaian kegiatan dalam model DKB dalam pembelajaran membaca pemahaman artikel mencapai $89,47 \%$. Dengan demikian dapat disimpulkan bahwa dosen model sangat memahami langkah-Iangkah pembelajaran model tersebut dengan baik.

6) Aktivitas mahasiswa dalam pembelajaran membaca pemahaman artikel berlangsung dengan balk. Hal itu dibuktikan dengan terlaksananya langkah-langkah kegiatan dalam model pembelajaran model DKB mencapai $89,47 \%$. Dengan terlaksananya hampir seluruh rangkaian kegiatan pembelajaran tersebut, dapat disimpulkan bahwa mahasiswa telah melakukan kegiatan pembelajaran secara optimal.

7) Dampak positif model pembelajaran DKB yang diperoleh berdasarkan hasil observasi, angket, dan wawancara, yaitu: (a) mengutamakan pembelajaran kolaboratif (gotong royong) untuk mencapai tujuan bersama; (b) mampu melibatkan semua anggota kelas dalam mencari, mengolah, dan melaporkan materi pelajaran untuk dipresentasikan di depan kelas; (c) dapat meningkatkan kepercayaan dan harga diri karena setiap anggota kelompok diberi kepercayaan untuk bertanggung jawab mengerjakan tugas; (d) mengembangkan sikap toleransi dalam berinteraksi dengan sesamanya; (e) meningkatkan keterampilan berbahasa, tidak hanya terbatas pada aspek membaca, tetapi menyimak, berbicara, dan menulis; (f) meningkatkan kreativitas berpikir; $(\mathrm{g})$ terjalin adanya saling membutuhkan satu sama lain. Dari penelitian ini diperoleh beberapa hal yang masih perlu dilakukan penyempurnaan yaitu: (a) kemungkinan terjadinya pengulangan (duplikasi) jawaban di 
saat anggota kelompok bernomor sama mempresentasikan hasil jawabannya dan (b) membutuhkan kecermatan dosen dalam membagi waktu agar setiap kelompok memiliki kesempatan untuk mempresentasikan hasil bekerja kelompoknya.

8) Model pembelajaranDKB secara efektif dapat meningkatkan kemampuan membaca pemahaman artikel pada mahasiswa Jurusan Pendidikan bahasa Daerah FPBS UPI. Hal-hal yang memperkuat bahwa model pembelajaran DKB efektif dalam meningkatkan kemampuan mahasiswa dalam pemahaman artikel dalam penelitian ini adalah, bahwa: (a) sebaran kegiatan belajar mahasiswa dalam model pembelajaran DKB le-bih merata karena, sejak awal mahasiswa telah mengetahui hal yang harus dipelajari masing-masing; (b) perpindahan materi belajar atau topik-topik diskusi dalam model pembelajaran DKB berlangsung secara konsisten dan Iebih cepat sehingga mempengaruhi banyaknya perolehan hasil belajar. (c) mahasiswa lebih berkonsentrasi mempersiapkan diri menyelesaikan pekerjaannya, karena dalam model pembelajaran DKB mahasiswa diberi tanggung jawab untuk dapat mempresentasikan setiap pekerjaannya baik individu maupun dalam kelompok; (d) terbinanya kemampuan berpikir kritis, karena pola diskusi dalam model pembelajaran DKB memberi kesempatan kepada mahasiswa untuk dapat mengemukakan gagasan, bekerja sama dan saling membantu dalam memahami materi pelajaran; (e) aktivitas belajar lebih tinggi, karena dalam model pembelajaran DKB masing-masing mahasiswa memiliki target materi yang harus dikuasainya; (f) motivasi belajar cukup tinggi, karena dalam model pembelajaran DKB mahasiswa diberi tanggung jawab untuk menyelesaikan pekerjaan masing-masing; dan (g) dalam model pembelajaran DKB dosen berperan sebagai moderator, memotivasi, dan mengatur jalannya diskusi, sehingga meningkatkan kepercayaan diri mahasiswa dalam mengemukakan pendapat.

\section{UCAPAN TERIMA KASIH}

Artikel ini diangkat dari laporan penelitian disertasi di Program Pascasarjana Universitas Pendidikan Indonesia. Oleh karena itu, ucapan terima kasih disampaikan kepada Promotor, Ko-Pormotor, Penguji Disertasi dan Bapak/Ibu Dosen Pascasarjana Universitas Negeri Malang. Selanjutnya ucapan terima kasih disampaikan kepada dua reviewer anonim yang telah membaca, mengoreksi dan memberi masukan terhadap artikel ini.

\section{DAFTAR PUSTAKA}

Akhadiat, Sabarti. 1988. Evaluasi dalam Pengajaran Bahasa, Jakarta: Depdikbud Dirjen Dikti.

Akhadiat, Sabarti. dan Mandar G.A. 1996. Pembinaan Kemampuan Menulis Bahasa Indonesia. Jakarta: Erlangga.

Anshori, Dadang, S. 2007. Peningkatan Kemampuan Berpikir Kritis Melalui Pengembangan Perkuliahan Tata Wacana yang Berbasis Analisis Wacana Kritis (Critical Discourse Analysis) (Jurnal). FPBS UPI: Jurnal pendidikan Bahasa, Sastra, dan Pengajarannya.

Arikunto, Suharsimi. 1995. Manjemen Penelitian. Jakarta: PT Rineka Cipta.

Departemen Pendidikan Nasional. 2006. Kamus Besar Bahasa Indonesia. Jakarta: Balai Pustaka.

Fraenkel, Jack.R. dan Norman E. Wallen. 1993. How to Design and Evaluate Research in Education. New York: 
McGraw-Hill. Inc.

Ibrahim, M., dkk. 2000. Pembelajaran Kooperatf Surabaya: University Press.

Isjoni. 2009. Pembelajaran Kooperatif Meningkatkan Kecerdasan Komunikasi antar Peserta Didik. Jogjakarta: Pustaka pelajar.

Iskandarwassid dan Sunendar, Dadang. 2008. Strategi Pembelajaran Bahasa. Bandung: SPs UPI dan PT Rosda Karya.

Iskandarwassid, 2001. “Efektivitas Model Mengajar Membaca Interpretatif dalam Meningkatkan Hasil Belajar Apresiasi Sastra Mahasiswa" (disertasi). PPS UPI Bandung: tidak diterbitkan.

Joyce, B., Weil M., dan Calhoun E. 2000. Models of Teaching. Boston: Allyn and Bacon.

Kagan, Spencer. 1994. Cooperative Learning. San Clemente, CA: Kagan Publishing

Keraf, G. 2004. Diksi dan Gaya Bahasa. Jakarta: Gramedia Pustaka Utama.

Keraf. G. 2001. Komposisi. Ende: Nusa lndah.

Lie, A. 2007. Cooperatif Learning: Mempraktikkan Cooperatif Learning di Ruang-ruang kelas. Jakarta: Grasindo.
Nurgiyantoro, Burhan. 2001. Penilaian dalam Pengajaran Bahasa dan Sastra. Yogyakarta: BPFE.-Yogyakarta.

Nurhadi. 2005. Bagaimana Cara Meningkatkan Kemampuan Membaca? Suatu Teknik Memahami Literatur yang Efisien. Bandung: Sinar Baru Algesindo.

Panjalu, Redi. 2008. Menulislah dengan Marah: Kiat Sukses Menulis Opini di Media Massa. Bandung: Nusa Media.

Rusyana, Y. 1984. "Penggunaan Bahasa Indonesia oleh Guru" dalam Bahasa dan Sastra dalam Gamitan. Bandung: CV Diponegoro.

Rusyana, Y. 1984. Bahasa dan Sastra dalam Gamitan Pendidikan. Bandung: CV Diponegoro.

Rusyana, Y. 1991. “Beberapa Pernyataan untuk Dipertanyakan tentang Pendidikan Bahasa". Makalah. Bandung: IKIP Bandung.

Slavin, R.E. 1985. Cooperative Learning (Research on Teaching Monograph Series). Broadway, New York Longman, Inc.

Smith, Frank. 1978. Psycolinguistic and Reading. New York: Rinehart dan Winston Inc 